Reprod. Nutr. Dévelop. 1980, 20 (4 A), 1061-1069.

\title{
Interactions between Maillard's reaction products, the microflora of the digestive tract and mineral metabolism
}

\author{
par Claude ANDRIEUX, E. SACQUET, L. GUÉGUEN * \\ Laboratoire des Animaux sans Germes, CNRS \\ * Station des Recherches de Nutrition, INRA, \\ 78350 jouy-en-josos, France.
}

Summary. 3 p. 100 of Maillard's reaction products (MRP), obtained by mild heating of glucose and glycine, were added to a semi-synthetic diet sterilized by irradiation. This resulted in increased dry matter excretion, more marked in axenic than in holoxenic rats, and in reduced apparent absorption of sodium and potassium in holoxenic rats. The addition of these products caused diarrhoea in axenic animals, thus preventing a good estimation of apparent absorption. It led to a significant decrease in the retention of calcium, phosphorus, magnesium and copper only in the axenic rats.

It is shown that MRP affect mineral metabolism and that the microflora plays a protective role in the physiology of digestion.

\section{Introduction.}

Several carbohydrates, and namely lactose, have been found to modify mineral metabolism in the rat (Atkinson, Kratzer and Stewart, 1957 ; Fournier and Digaud, 1969 ; Bouvet, 1973 ; Ali and Evans, 1973 ; Fournier, Fournier and Digaud, 1974). This lactose action depends on the sterilization procedure of the feed. An irradiated lactosecontaining diet has a favourable effect on the retention of numerous minerals, whereas the same autoclaved diet leads to a reduction of that retention and may even reverse it (Andrieux, Guéguen and Sacquet, 1980). During autociaving, part of the lactose, logether with the free amino groups of casein, induces Maillard's reaction (Reynold, 1963, 1965). This reaction has three effects : (i) reduction of the amount of lactose (ii) modification of some essential amino acids, and (iii) formation of substances which may affect the physiology of digestion (Adrian, 1974 ; Bender, 1979). It is impossible to determine accurately which of these effects is responsible for the changes in mineral metabolism when the lactose-containing dief is autoclaved.

This paper attempts to determine the role of Maillard's reaction products (MRP), excluding the effects due to a decrease in the dietary lactose level or to an alteration of some diefary components such as lysine. We have also tried to establish whether the bacterial flora of the digestive tract changes this role of MRP on mineral metabolism. 


\section{Material and methods.}

We obtained Maillard's reaction products by beating a mixture of glycine and glucose.

An equimolar mixture of glucose and glycine was dissolved in a small volume of water to obtain a final water content of $20 \mathrm{p}$. 100. The mixture was autoclaved at $120^{\circ} \mathrm{C}$ for $20 \mathrm{~min}$; the temperature rise of the mixture was included in that heating time. In those conditions, the reaction only produced soluble compounds or premelanoidins. The amount of glucose determined by glucose oxidase and that of glycine determined by autoanalysis (Beckman Multichrom B apparatus) showed that 16 p. 100 of the glucose and 25 p. 100 of the glycine were not transformed. The pasty autoclaved preparation was diluted 10 times and then lyophilized.

A given amont of this lyophilized preparation (3.84 p. 100, i.e. 3 p. 100 MRP) was added to the experimental feed $(\operatorname{diet} M)$. The control feed $(\operatorname{diet} T)$ was admixed with glycine and glucose in proportions equal to the untransformed fraction of the heated preparation in diet $M$.

Both the diets were sterilized by gamma irradiation at $4 \mathrm{Mrads}$ in vacuum-sealed double polyethylene bags.

At weaning, holoxenic and axenic rats were each divided into two groups of 7 rats each (a total of 4 groups); one group was fed the $T$ diet and the other the $M$ diet in the form of a thick paste ( 50 p. 100 DM). At 4 weeks of age, they were isolated in metabolism crates and at 6 weeks they were subjected to balance trials for 10 days.

\section{TABLE 1}

Dief composition (p. 100)

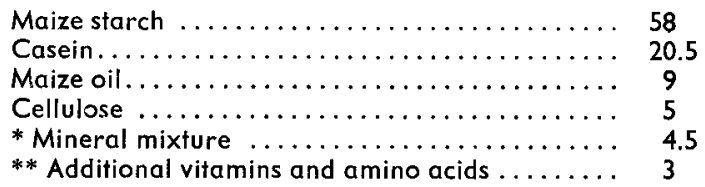

* The mineral mixture includes (in $\mathrm{g} \mathrm{p.} 100 \mathrm{~g}$ of diet). Calcium carbonate 1.3 ; monocalcium phosphate 0.55 ; dipotassium phosphate 1.125 ; disodium phosphate 0.5 ; sodium chloride 0.25 ; magnesium sulfate 0.6 ; iron citrate 0.1 ; zinc sulfate 0.025 ; mangansese sulfate 0.040 ; copper sulfate 0.006 ; potassium iodide 0.003 ; cobalt chloride 0.001 . The mineral composition of each preparation was controlled by assay. The complete diet contained a mean (in $\mathrm{mg} / \mathrm{g}$ dry matter) of $\mathrm{Ca}: 6.8 ; \mathrm{P}$ : $5.5 ; \mathrm{K}: 4.9 ; \mathrm{Na}: 4.1 ; \mathrm{Mg}: 0.64 ; \mathrm{Mn}: 0.185 ; \mathrm{Fe}: 0.27 ; \mathrm{Zn}: 0.23 ; \mathrm{Cu}: 0.015$.

** In Andrieux, Guéguen and Sacquet, 1980.

The proportion of $\mathrm{Mg}, \mathrm{Mn}, \mathrm{Fe}, \mathrm{Zn}$ and $\mathrm{Cu}$ in the feeds and the excreta was measured by atomic absorption spectrometry (IL 151 apparatus), that of $\mathrm{Ca}, \mathrm{K}$ and $\mathrm{Na}$ by flame emission photometry (Eppenderf apparatus), and the proportion of $P$ by colorimetry (Misson's reaction).

Presentation of results.

The results of the mineral balances are expressed in percentage of the amount of minerals ingested. 


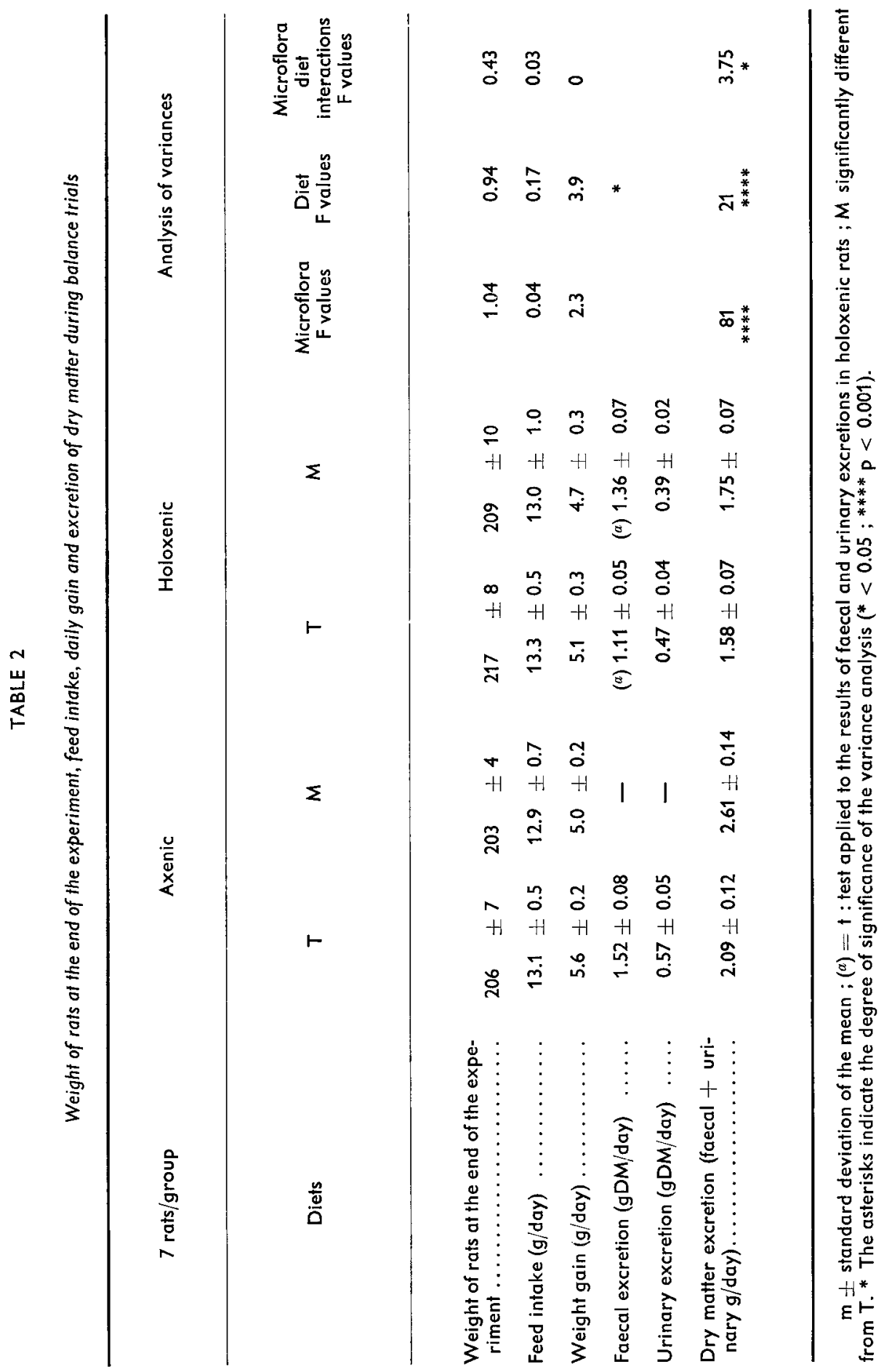


Two statistical methods (see Results) were used to analyze the results :

- Student's t-test for measuring the effect of diet $M$ on apparent absorption, urinary excretion and mineral retention in holoxenic rats and mineral retention in axenic rats ;

- Two-way variance analysis (Snedecor and Cochran, 1957) for analyzing all the results on mineral retention, feed intake, weight gain and dry matter excretion.

\section{Results.}

The feed intake, weight gain and dry matter excretion of the rats during the pediod of balance measurements are shown in table 2 . The feed intake level was

\section{TABLE 3}

Mineral balances in holoxenic rats

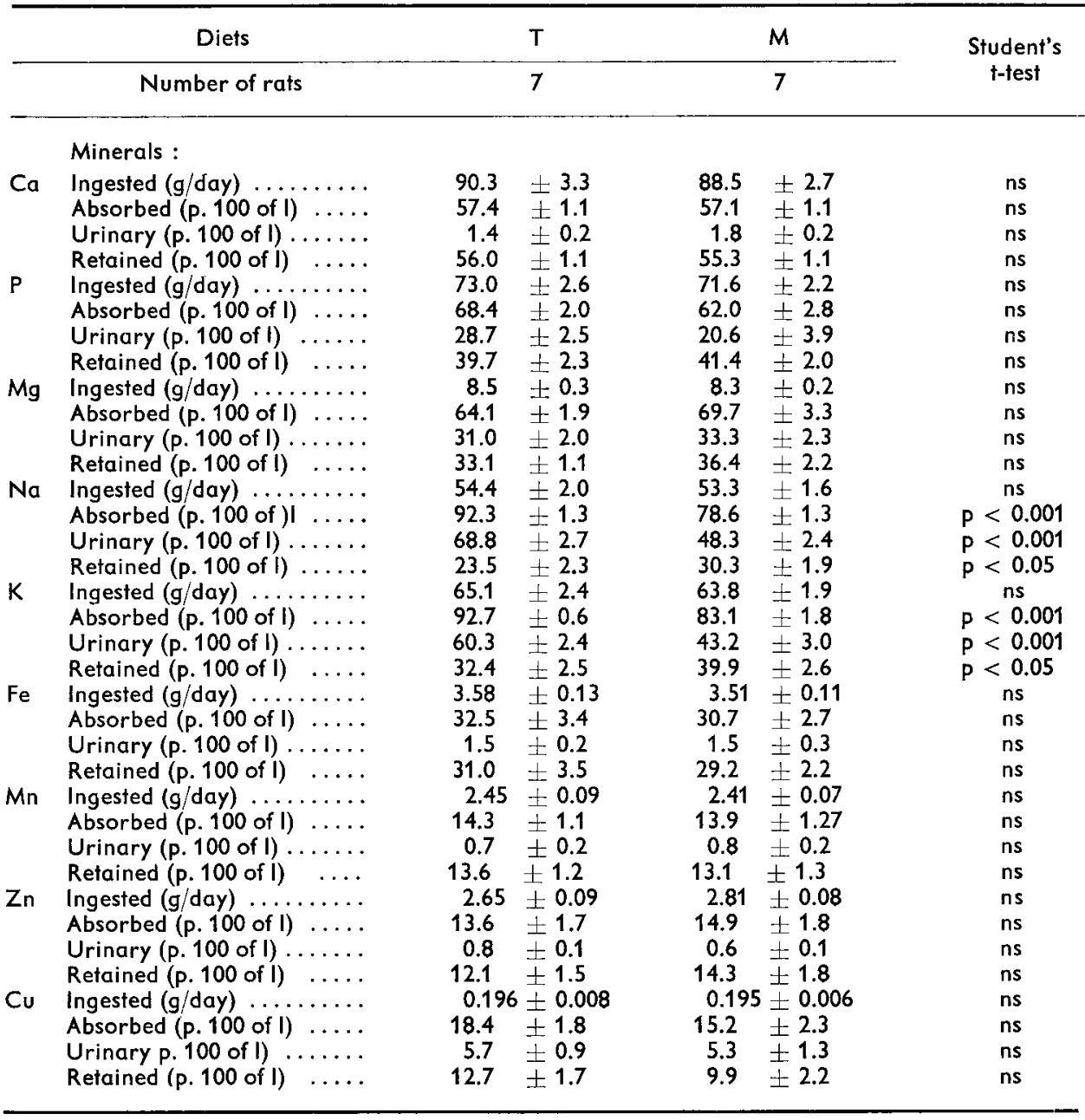


comparable in the 4 groups of rats, whose weight at the end of the experiment was not significantly changed. However, during the balance period, growth weight was slightly lower in the rats fed diet $M(P<0.05)$. The addition of 3 p. 100 of MRP to the diet led to an increase in faecal dry matter excretion $(P<0.05)$. In the axenic animals, those substances caused diarrhoea, thus excluding a suitable separation of the urine from the faeces. The variations in dry matter excretion according to microflora-diet factors were thus considered as a whole (urine + faeces). The rise in that excretion as affected by diet $M$ was highly significant $(P<0.001)$, and was more marked in axenic than in holoxenic animals (significant interaction, $\mathrm{P}<0.05$ ).

Because the faeces and the urine of axenic rats receiving died $M$ were not well separated, variations in the apparent absorption and the urinary excretion of minerals ( $\mathrm{Ca}, \mathrm{P}, \mathrm{Mg}, \mathrm{Na}, \mathrm{K}, \mathrm{Fe}, \mathrm{Mn}, \mathrm{Zn}, \mathrm{Cu}$ ) were only studied in holoxenic rats. The effect of the MRP on mineral retention was analyzed in both axenic and holoxenic animals.

The results of mineral balances in the holoxenic rats are given in table 3 . Only $\mathrm{Na}$ and $\mathrm{K}$ metabolisms were changed by diet $\mathrm{M}$. The apparent absorption of those minerals was markedly reduced $(P<0.001)$. A reduction in their urinary excretion compensated for this effect, and their retention was higher in rats fed diet $M$ than in rats given diet $T(P<0.05)$.

TABLE 4

Mineral balances in axenic rats

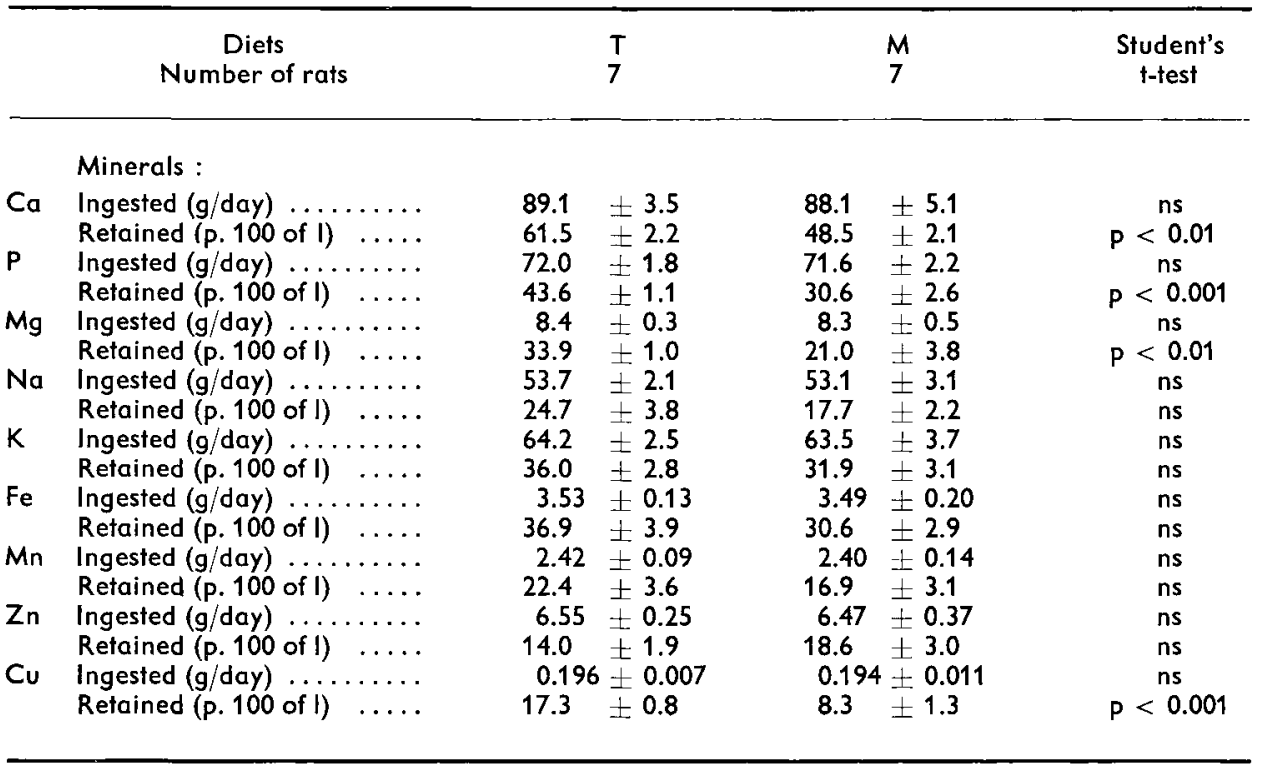

Diet $M$ significantly reduced $\mathrm{Ca}, \mathrm{P}, \mathrm{Mg}$ and $\mathrm{Cu}$ retention in axenic animals but not in holoxenic ones. The analysis of variance (table 5) confirmed to results of Student's t-test, i.e. the microflora-diet interaction was significant : $P<0.001$ for $\mathrm{Ca}, \mathrm{P}$, $\mathrm{Mg} ; \mathrm{P}<0.05$ for Cu. 
That analysis evidenced an interaction $(P<0.05)$ of the two factors on Na retention : dief $M$ had an opposite effect on the retention of this mineral in both axenic and holoxenic rats.

TABLE 5

Mineral retention during the period of balance measurements : Two-way variance analysis (microflora and dief)

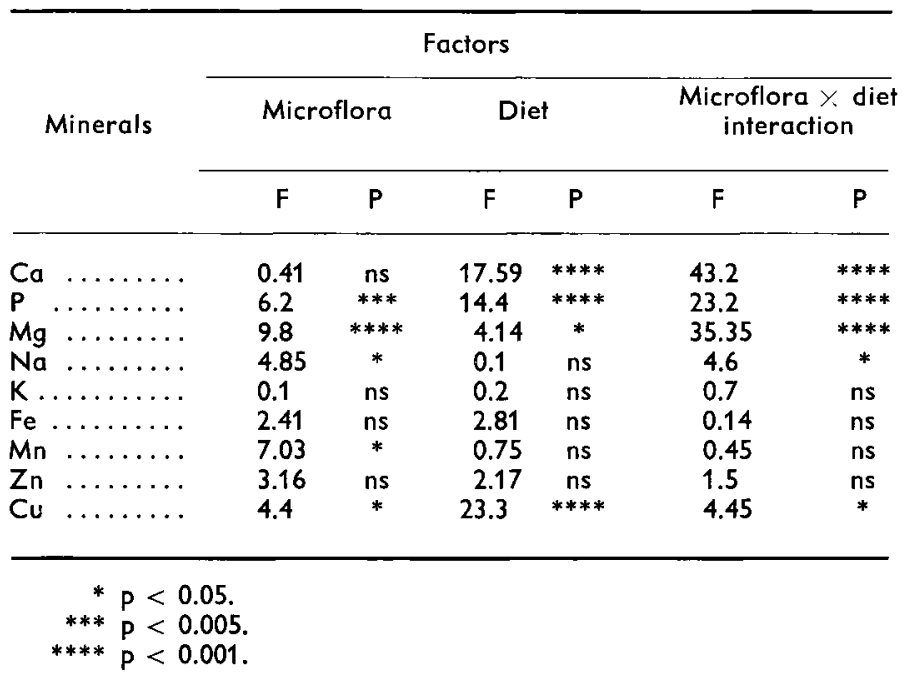

\section{Discussion.}

The mineral composition of the diet used in this experiment was rather different from that of the previous experiment (Andrieux, Guéguen and Sacquet, 1980). Thus, the two sets of data cannot be compared. However, the microflora exerted similar effects on the animals receiving diet $\mathrm{T}$, except in the case of $\mathrm{Mg}$ which was equally retained in axenic and holoxenic animals in this experiment; in the previous experiment, it was better retained in axenic than in holoxenic rats.

The effects of a heated glucose-glycine mixture vary widely according to the temperature, heating time and dietary level of the premelanoidins (Adrian et al., 1966). At a low level they increase the appetite, and at a high level they reduce the amounts ingested, the protein utilization of the diet and the weight gain. In our experiment, no effect was observed on the feed intake level and the weight of the rats at the end of the experiment.

The increase in the dry matter excretion caused by died $M$ was similar to that obtained in the previous experiment with the autoclaved lactose-containing diet. This suggests that the increase in dry matter excretion probably did not result from the formation of indigestible substances during autoclaving, but from the action of Maillard's reaction products on the digestive physiology. According to various authors (Adrian and Frangne, 1973 ; Chong Min Lee, Chichester and Tung-Ching Lee, 1977 ; 
Johnson, Baker and Perkins, 1979), MRP reduce the activity of some gastrointestinal enzymes such as proteases and disaccharidases.

Thus, the action of MRP (obtained by heating glucose and glycine) on dry matter excretion resembled that of the autoclaved lactose-containing feed; this was also the case of their action on mineral metabolism. The retention of some minerals ( $\mathrm{Ca}$, $\mathrm{P}, \mathrm{Mg}, \mathrm{Cu}$ ) was reduced in axenic rats. The presence of a bacterial flora led to the disappearance of the MRP effect in the holoxenic rat.

The decrease in apparent $\mathrm{Na}$ and $\mathrm{K}$ absorption in the holoxenic rats of this experiment was astonishing as compared to the results obtained with the autoclaved lactose-containing diet. In the latter case, there was a decrease in apparent $\mathrm{Na}$ and $\mathrm{K}$ absorption in axenic, but not in holoxenic, rats. The diarrhoea observed in axenic rats in the present experiment might be related to an even larger reduction of $\mathrm{Na}$ and $\mathrm{K}$ absorption. The lower apparent absorption of those two minerals, due to the absence of microflora on the one hand and to MRP on the other, may depend on similar mechanisms. According to Gordon and Wostmann (1973), the presence of large amounts of mucopolysaccharides in the axenic rat caecum brings about the retention of some cations, reduction in the amount of $\mathrm{Cl}$-ions and the blockage of the sodium pump as well as the water transport mechanisms. The MRP might act by increasing the formation of these mucopolysaccharides or because they possess some of the chemical properties of those molecules.

The differences between the effect of the MRP of this experiment and the effects of an autoclaved lactose-containing diet might be explained by the fact that Maillard's reaction products vary considerably depending on the sugar or amino acid involved and on the procedure for heating the preparation. These differences in MRP composition and diet composition most likely account for the divergences between the results of the experiments of Adrian and Boisselot-Lefebvres (1977), Senior, Wolinsky and Brinkman (1978) and ours as regards the effect of premelanoidins on calcium absorption. Indeed, those authors observed a favourable premelanoidin action on calcium absorption and a considerable increase of its urinary excretion.

In the light of our present knowledge, it is impossible to determine through which mechanisms Maillard's reaction products act on mineral retention.

Two hypotheses may explain the palliative role of the bacterial flora. According to one, the flora destroys the MRP. Various authors have observed this catabolic action of intestinal bacteria (Adrian and Susbielle, 1975 ; Sgarbieri et al., 1973 ; Tanaka, Lee and Chichester, 1975 ; Johnson, Baker and Perkins, 1979). However, the effect can only be exerted if MRP destruction occurs proximal to the absorption site of the mineral considered. In the holoxenic rat, the microflora is found throughout the digestive tract, but is much more abundant in the caecum and large bowel (Raibaud et al., 1966).

Thus, either the stomachal or ileal microflora destroys the premelanoidins or there is a rather high absorption of $\mathrm{Ca}, \mathrm{P}, \mathrm{Mg}$ and $\mathrm{Cu}$ in the caecum and large bowel. This last supposition is far from being established ; Marcus and Lengemann (1962) and Cramer and Copp (1959) consider that in that part of the intestine, calcium absorption is negligible.

According to the second hypothesis, the absorption of these minerals is poor in 
the caecum of holoxenic rats, whereas it is significant in the axenic rat caecum which is voluminous and has a much longer transit time.

Acknowledgements. - We wish to thank Mrs. Rerat for translating this manuscript into English.

Reçu en février 1980. Accepté en mars 1980.

Résumé. L'addition à un aliment semi-synthétique stérilisé par irradiation de $3 \mathrm{p} .100$ de produits de la réaction de Maillard (PRM) obtenus par chauffage ménagé de glucose et de glycine provoque une augmentation de l'excrétion de matière sèche plus importante chez les rats axéniques que chez les rats holoxéniques. Ces substances réduisent l'absorption apparente du sodium et du potassium chez les rats holoxéniques. Chez les rats axéniques elles provoquent une diarrhée qui exclut une bonne estimation de l'absorption apparente. Elles déterminent chez les seuls rats axéniques une diminution significative de la rétention du calcium, du phosphore, du magnésium et du cuivre.

Ces résultats sont discutés : ils mettent en évidence un effet des PRM sur le métabolisme minéral et un rôle profecteur de la flore microbienne sur la physiologie digestive.

\section{References}

ADRIAN J., 1974. Nutritional and physiological consequences of the Maillard reaction. World Rev. Nutr. Diet., 19, 71-22.

ADRIAN J., BOISSELOT-LEFEBVRES J., 1977. Interrelations entre les produits de la réaction de Maillard et le métabolisme calcique, Cah. Nutr. Diet., 12, 233-234.

ADRIAN J., FRANGNE R., 1973. La réaction de Maillard. 8. Influence des prémélanoīdines sur la digestibilité azotée et la protéolyse. Ann. Nutr. Alim., 27, 111-123.

ADRIAN J., FRANGNE R., PETIT L., GODON B., BARBIER J., 1966. Répercussions nutritionnelles des produits solubles formés au cours de la réaction de Maillard. Ann. Nutr. Alim., 20, 257-277.

ADRIAN J., SUSBIELLE H., 1975. La réaction de Maillard. 10. Effets des prémélanoïdines sur la reproduction du rat. Ann. Nutr. Alim., 29, 151-158.

ALI R., EVANS J. L., 1973. Lactose and calcium metabolism : A review. J. Agr. Univ. P. R., 57, 149-164. ANDRIEUX C., GUÉGUEN L., SACQUET E., 1980. Effects of la ctose and mode of sterliization of a lactose diet on mineral metabolism in germ-free and conventional rats. Reprod. Nutr. Develop., 20, $119-138$.

ATKINSON R. L., KRATZER F. H., STEWART G. F., 1957. Lactose in animal and human feeding : A review. J. Dairy Sci., 40, 1114-32.

BENDER A. E., 1979. The effect of heat on protein-rich foods, 411-426. In W. K. DOWNEY food quality and nutrition, Research priorities for thermal processing. Appl. Sci. Publ. LTD. London.

BOUVET D., 1973. Influence sur le rat d'une ingestion prolongée de lactose sur la teneur en fer de la ferritine et de l'hémosiderine. C. R. Acad. Sci. Paris, sér., D, 276, 177-180.

CHONG MIN LEE, CHICHESTER C. O., TUNG-CHING LEE, 1977. Effect of Maillard reaction products on disaccharidase activities in the rat. J. Agric. Food Chem., 25, 775-778.

CRAMER C. F., COPP D. H., 1959. Progress and rate of obsorption of radiostrontium through intestinal tracts of rats. Proc. Soc. exp. Biol. Med., 102, 514-517.

FOURNIER P., DIGAUD A., 1969. Effects chez le rat de l'ingestion simultanée de lactose ef de $\mathrm{Zn}^{65}$ sur l'absorption et la rétention de cet élément. C. R. Acad. Sci. Paris, sér. D, 269, 2001-1003.

FOURNIER P., FOURNIER A., DIGAUD A., 1974. Augmentation chez le rat de l'utilisation de $\mathrm{Co}^{58}$ du fait de l'ingestion simultanée de certains glucides. C. R. Soc. Biol., 168, 244-247.

GORDON H. A., WOSTMANN B. S., 1973. Chronic mild diarrhea in germfree rodents : A model portraying host-flora synergism, 593-601. In J. B. HENEGHAM. Germfree research. Biological effect of gnotobiotic environments. Acad. Press, New York and London.

HODGE J. E., 1953. Dehydrated food : Chemistry of browning reactions in model systems. J. Agric. Food Chem., 1, 928-943. 
JOHNSON G. H., BAKER D. H., PERKINS E. G., 1979. Nutritional implications of the Maillard reaction. The metabolism of fructose phenylalanine in the rat. J. Nutr., 109, 590-596.

MARCUS C. S., LENGEMANN F. W., 1962. Absorption of $\mathrm{Ca}^{45}$ and $\mathrm{Sr}^{85}$ from solid and liquid food at various levels of the alimentary tract of the rat. J. Nutr., 77, 155-160.

PETIT L., 1959. Recherches sur la réaction de Maillard. Ann. Technol., 1, 5-33.

RAIBAUD P., DICKINSON A. B., SACQUET E., CHARLIER H., MOCQUOT G., 1966. La microflore du tube digestif du rat. II. Dénombrement de différents genres microbiens dans l'estomac et l'intestin des rats conventionnels. Ann. Inst. Pasteur, 110, 861-876.

REYNOLD T. M., 1963. Chemistry of non-enzymatic browning. I. The reaction between aldoses and amins. Adv. Food Res., 12, 1-52.

REYNOLD T. M., 1965. Chemistry of non-enzymatic browning II. Adv. Food Res., 14, 168-283.

SENIOR J. A., WOLINSKY I., BRINKMAN G. L., 1978. Diets based on autoclaved skim-milk powder. Caries Res., 12, 275-283.

SGARBIERI V. C., AMAYA J., TANAKA M., CHICHESTER C. O., 1973. Nutritional consequences of the Maillard reaction. Amino acid availability from fructose-leucine and fructose-tryptophan in the rat. J. Nutr., 103, 657-663.

SNEDECOR G. W., COCHRAN W. G., 1957. Méthodes statistiques. 6e ed. A.C.T.A. Paris, 379-424.

TANAKA M., LEE T. C., CHICHESTER C. O., 1975. Nutritional consequences on the Maillard reaction. The absorption of fructose $L$ tryptophan in the large intestine of the rat. J. Nutr., 105, 989-994. 